\title{
Severe combined immunodeficiency due to CTPS1 deficiency
}

INSERM

\section{Source}

INSERM. (1999). Orphanet: an online rare disease and orphan drug data base. Severe combined immunodeficiency due to CTPS1 deficiency. ORPHA:420573

Severe combined immunodeficiency (SCID) due to CTPS1 deficiency is a rare primary immunodeficiency disorder due to impaired capacity of activated T- and B-cells to proliferate in response to antigen receptor-mediated activation characterized by earlyonset, severe, persistent and/or recurrent viral infections due to Epstein-Barr virus (EBV) and Varicella Zoster virus (VZV, including generalized varicella)), as well as recurrent sinopulmonary bacterial infections due to encapsulated pathogens. 